\title{
Influence of the lugworm Arenicola marina on porewater nutrient profiles of sand flat sediments
}

\author{
Markus Hüttel \\ Zoologisches Institut der Universität Kiel, Marine Ökologie und Systematik, Olshausenstrasse, D-2300 Kiel, \\ Federal Republic of Germany
}

\begin{abstract}
Bioturbation by the lugworm Arenicola marina L. caused specific changes in porewater nutrient profiles of sandflat sediments. In 2 in situ container experiments, A. marina increased nitrate and decreased ammonia concentrations at the depth of its burrows. This indicates that $A$. marina stimulates nitrification in this sediment layer through oxygen supply via its ventilation current. The enlarged zone of nitrification promotes denitrification and thereby, nitrogen release from sediments. Silicate concentrations in the porewater were also affected by A. marina bioturbation. Silicate was flushed out of the sediment with the ventilation current. These findings emphasize the important role of A. marina for nutrient release from Wadden Sea sediments.
\end{abstract}

\section{INTRODUCTION}

Nutrient profiles in porewater of soft bottom sediments are shaped mainly by reactions associated with the decomposition of organic matter and other biogenic compounds such as siliceous skeletons of diatoms (Berner 1971, 1979, 1980). Decomposition pathways depend on the electron acceptor involved in the reaction where molecular oxygen supplies the highest metabolic energy yield for the organisms (Aller 1982). The composition of porewater in different sediment layers depends on the dominating decomposition pathways at the sediment depth under consideration. Typical gradients of porewater constituents governed mainly by molecular diffusion are found in sediments with undisturbed stratification (Berner 1976). In contrast to this, nutrient profiles of densely populated sediments exhibit characteristic anomalies due to macrobenthic bioturbation (Guinasso \& Schink 1975, Rhoads et al. 1977, Aller 1978, Aller \& Yingst 1985, Aller \& Aller 1986, Asmus 1986). By increasing exchange processes between sediment and overlying water, steep concentration gradients in the uppermost sediment layer are diminished (Aller 1982, Henriksen et al. 1983).

The aim of this work was to investigate the effect of the polychaete Arenicola marina L. on nutrient profiles of intertidal sandflat sediments. The sheltered flats of the Wadden Sea, extending along the Dutch, German and Danish coasts, are areas where organic matter imported from the North Sea supports a rich benthic macrofauna which surpasses the macrofauna of the central North Sea by 2 - to 10 -fold in biomass (Thiel et al. 1984, Reise 1985, Beukema \& Cadée 1986, Gerlach 1987).

The lugworm Arenicola marina is the dominant polychaete (in biomass) of the intertidal sand flats and is characterized by its strong bioturbation (Reise 1985). Adults may reach a body length of $36 \mathrm{~cm}$ but generally a length of $25 \mathrm{~cm}$ is not exceeded (Ashworth 1904 Krüger 1971). A. marina lives in an L-shaped tube which extends as much as $30 \mathrm{~cm}$ down into the sediment (Wells 1945, Krüger 1959). When feeding, the polychaete stays in the lower part of the burrow, named the gallery, and swallows sediment from the feeding pocket which terminates the tube (see Fig. 3). The removed sediment is replaced by oxic sediment which sinks from the surface through the narrow quicksand column termed the head shaft of the burrow (Rijken 1979. Newell 1979). At the top of the column a funnel develops which acts as a detritus trap. A. marina feeds on this detritus as well as on diatoms and bacteria sinking downwards from the surface to the feeding pocket (Fauchald \& Jumars 1979). By means of peristaltic movements, it pumps oxygenated water through its burrow. Overlying water enters the open tube of the tail shaft and flows downwards into the gallery, supply. ing the polychaete with oxygen (Krüger 1966, 1971). 


\section{MATERIALS AND METHODS}

Experiments were carried out on the tidal flats of Königshafen, a bay of the island Sylt, North Sea $\left(55^{\circ} 02^{\prime} \mathrm{N}, 8^{\circ} 06^{\prime} \mathrm{E}\right)$. Sediments consist of relatively coarse sand (median $431 \mathrm{\mu m}$ ) with an organic content of 0.4 to $1.2 \%$ (determined as weight loss at $550^{\circ} \mathrm{C}$ ). During the investigation period, the redox potential discontinuity (RPD) was found at 3.5 to $5 \mathrm{~cm}$ sediment depth. Salinity remains close to $31 \%$. Mean water temperature ranges from $15^{\circ} \mathrm{C}$ in summer to $4^{\circ} \mathrm{C}$ in winter. Tidal amplitude is $1.8 \mathrm{~m}$. The experimental plot was situated close to the average low water level; mean exposure time at low tide was $2 \mathrm{~h}$. Tidal current speed above the experimental plot ranged from 6 to $10 \mathrm{~cm} \mathrm{~s}^{-1}$.

Two in situ experiments were carried out to investigate the impact of the polychaete Arenicola marina on nutrient concentrations in porewater of the sandflat sediment. Porewater concentrations of nitrate, nitrite ammonia (sensitive to oxygen) and silicate (relatively insensitive to oxygen) were measured.

Container experiment. This experiment was designed to investigate the qualitative and quantitative influence of Arenicola marina on nutrient profiles in sandy sediment under in situ conditions. Seven cylindrical polyethylene containers with a height of $47 \mathrm{~cm}$ and a diameter of $30 \mathrm{~cm}$ were filled with $30 \mathrm{~cm}^{3}$ of dry sieved sand (median $430 \mu \mathrm{m}$, originating from the same tidal flat) and were embedded in the sediment of the tidal flat. The bottom of the containers had gauzecovered openings ( $2 \mathrm{~cm}$ in diameter, $100 \mu \mathrm{m}$ gauze) to permit natural porewater flow. The sides of the containers where they protruded from the sediment surface also had gauze-covered openings $17 \mathrm{~cm}$ diameter, 500 um gauze) to prevent water retention by the containers at low tide. The tops of the containers were closed with gauze (1500 $\mu \mathrm{m})$ (Fig. 1).

Four weeks after the containers were placed into the tidal sand flat, different numbers of small juvenile Arenicola marina ( 8 to $10 \mathrm{~cm}$ length, 3 to $4 \mathrm{~g}$ wet $\mathrm{wt}$ ) were put into 6 of them; 1 container remained without lugworms as a control (Table 1). Juveniles are easier to handle as they are not as fragile as adults and were not disturbed by the relatively small size of the containers. The experiment was performed twice, once in September, and a replication in October.

Sediment block experiment. This experiment was conducted to investigate the effect of adult Arenicola marina on mutrient profiles of the natural, undisturbed sandflat sediment. On the tidal flat, 2 square blocks of sediment, with a surface measuring $1 \times 1 \mathrm{~m}$, were enclosed by pushing a $35 \mathrm{~cm}$ broad PVC-foil into the sediment. Sediment structure and fauna of the 2 blocks were not disturbed. Adult $A$. marina were placed in one of the 2 blocks to increase their abundance (Table 2). In

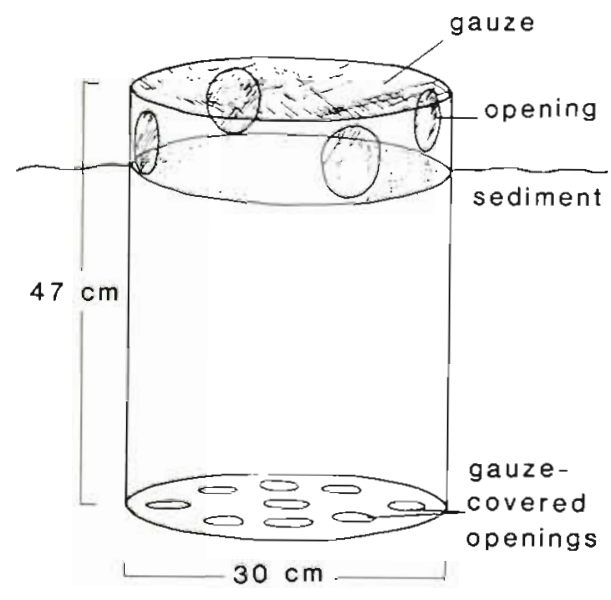

Fig. 1 The sediment container

Table 1. Arenicola marina. Number and weight in the containers at the beginning of the experiment

\begin{tabular}{ccc|}
$\begin{array}{c}\text { Container } \\
\text { no. }\end{array}$ & $\begin{array}{c}\text { No. of } \\
\text { Arenicola }\end{array}$ & $\begin{array}{c}\text { Total wet } \\
\text { weight }(\mathrm{g})\end{array}$ \\
\hline 0 & 0 & 0 \\
1 & 4 & 10.9 \\
2 & 5 & 16.8 \\
3 & 8 & 21.3 \\
4 & 10 & 33.2 \\
5 & 14 & 43.6 \\
6 & 16 & 44.1 \\
\hline
\end{tabular}

a third sediment block with equal dimensions, all $A$. marina were removed carefully and a gauze mat $(1 \times 1 \mathrm{~m}, 1500 \mu \mathrm{m}$ mesh size) was embedded horizontally at $5 \mathrm{~cm}$ sediment depth to prevent lugworm immigration (Reise 1983). This was done 3 mo before initiation of the experiment.

The duration of the experiment was $8 \mathrm{wk}$ with a sampling frequency of 2 wk. On each occasion 4 to 6 porewater nutrient profiles were measured in the 3 blocks. At the end of the experiment 22 nutrient profiles had been measured in the block with natural $A$. marina abundance and 18 profiles in each of the other 2 blocks with manipulated abundances

Sampling device. To observe the changes in porewater nutrient concentrations, a multiple porewater sampler was designed, which allows sampling without

Table 2. Arenicola marina. Abundances in the 3 experimental blocks during the experiment

\begin{tabular}{|cc|}
\hline Block & Abundance \\
\hline 1: A. marina exclusion & 0 \\
2: Natural A marina abundance & 33 \\
3: Increased A. marina abundance & 220 \\
\hline
\end{tabular}


damaging the sediment block examined. Multiple porewater samples can be collected from precise locations at 6 depth intervals while maintaining their anaerobic properities.

The sampler consists of 2 components: the sampling probe and the suction apparatus (Fig. 2). The probe is made of a high-density PVC pipe $(30 \mathrm{~cm}$ long and $1 \mathrm{~cm}$ in diameter). The lower end of the pipe is sealed with a conical tip of strong plastic. The tube has 2 gauzecovered openings at each of 6 depth intervals $(3,5,7$, $10,15,20 \mathrm{~cm})$, which are connected to Tygon tubing with $0.8 \mathrm{~mm}$ inner diameter for sample withdrawal. To establish sampler depth a plastic disk is attached to the

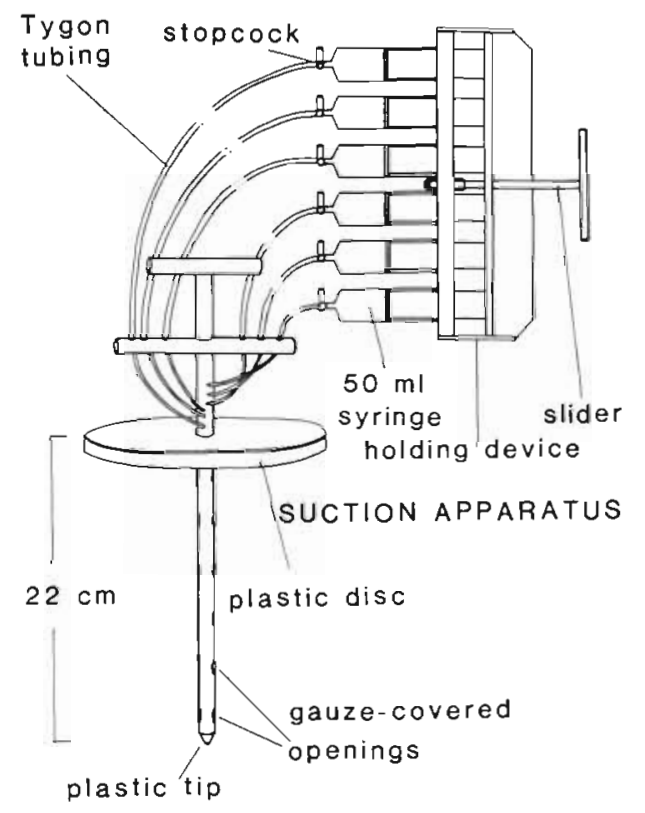

SAMPLING PROBE

Fig. 2. The sampling device

PVC pipe. To collect porewater samples, the suction apparatus is joined to the tubing from the probe. The suction apparatus consists of six $50 \mathrm{ml}$ syringes fixed to a strong holding device. The pistons of the syringes are attached to a connecting slider which permits all 6 pistons to be drawn out simultaneously.

After discarding the first $2 \mathrm{ml}$ of sample, $20 \mathrm{ml}$ porewater was extracted from each of 6 sampling depths. As pore volume makes up 40 to $50 \%$ of sediment volume, the extracted samples can be calculated to correspond to a drained sediment cylinder of about $3 \mathrm{~cm}$ height and $5 \mathrm{~cm}$ diameter. Simultaneous extraction of porewater from the different sediment layers hinders mixing of samples and the disc covering the sediment surface prevents inflow of overlying water. Analysis of nutrients was performed immediately after sampling according to the methods of Grasshoff et al. (1983).

\section{RESLLTS}

\section{Container experiment}

As documented by feeding funnels and fecal casts, burrowing and feeding activities of juvenile Arenicola marina were not affected by the containers. Sectioning of the sediment cores after the experiment confirmed this observation. The galleries were found consistently at 15 to $20 \mathrm{~cm}$ depth, which is normal for these juvenile polychaetes with a mean weight of 3 to $4 \mathrm{~g}$ (wet $\mathrm{wt}$ ) (Fig. 3). Tail shaft and gallery of the burrows were coated with a $1 \mathrm{~mm}$ thick mucous wall which had a reddish inner surface (ferrous hydroxides) down to $6 \mathrm{~cm}$ sediment depth and was grey in the gallery (ferrous bisulfide).

As the lugworm rejects coarse particles when feeding, shell debris, small stones and plant fibres accumulate in the sediment layer of the gallery and feeding pocket (Van Straaten 1952). Consequently

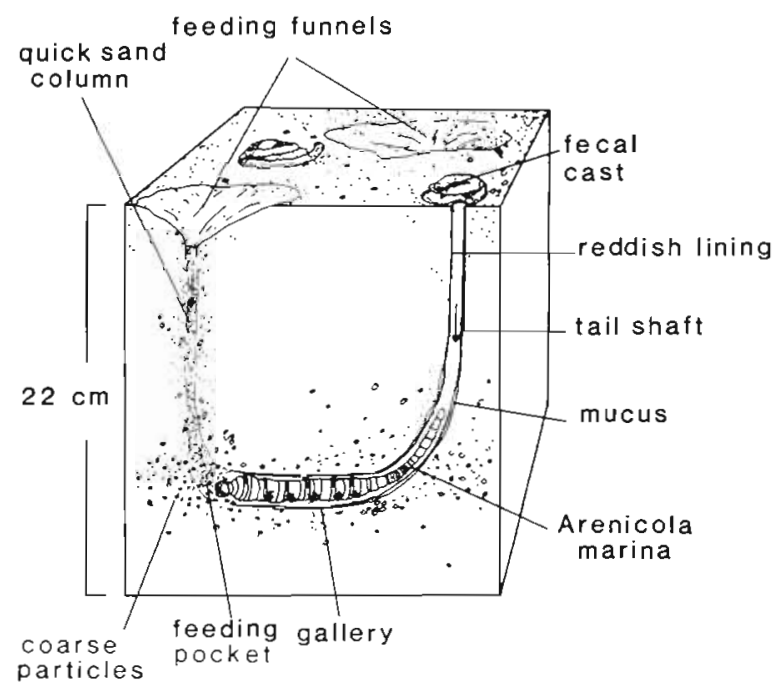

Fig. 3. Arenicola marina. The burrow of the lugworm. Arrows indicate movement of sediment (head shaft) and water (tail shaft)

the maximum median grain size in the containers inhabited by Arenicola marina was reached at 15 to $20 \mathrm{~cm}$ depth (Table 3 ). The head shaft of the burrows consisted of a narrow column of brownish, oxic sediment which moved downward from the sediment surface.

Increasing the abundance of Arenicola marina caused an increase in concentration of oxidized nitrogen compounds in the porewater down to $20 \mathrm{~cm}$ sediment depth (Figs. 4 and 5). The maximum increases in nitrate and nitrite were measured in the 15 to $20 \mathrm{~cm}$ depth layer. In Table 4 nitrate and nitrite concentrations of the control container and the containers with highest $A$. marina abundance are listed. 
Table 3. Grain-size distribution and organic content of the sediment in Container 5 with 14 juvenile Arenicola marina. Porosity $=$ volume porespace/volume sediment particles

\begin{tabular}{|cccc|}
$\begin{array}{l}\text { Depth } \\
(\mathrm{cm})\end{array}$ & $\begin{array}{c}\text { Grain size, } \mu \mathrm{m} \\
\text { (median) }\end{array}$ & Porosity & $\begin{array}{c}\text { Organic } \\
\text { content }(\%)\end{array}$ \\
\hline $0-1$ & & & 0.73 \\
$1-3$ & 402 & 0.63 & 0.47 \\
$3-7$ & & 0.41 & 0.27 \\
$7-11$ & 420 & 0.16 \\
$11-15$ & & 0.39 & 0.25 \\
$15-20$ & 436 & 0.46 & 0.30 \\
$0-20$ & 423 & 0.29 \\
\hline
\end{tabular}

Calculated for an Arenicola marina standard biomass of $100 \mathrm{~g}$ (wet wt) $\mathrm{m}^{-2}$, the mean increase in nitrate concentration at 15 to $20 \mathrm{~cm}$ depth was $1.5 \mu \mathrm{mol} \mathrm{l^{-1 }}$ in September and October. Increase in nitrite concentration amounted to $0.15 \mu \mathrm{mol} \mathrm{l}^{-1}$ in September and $0.35 \mu \mathrm{mol} l^{-1}$ in October relative to an $A$. marina biomass of $100 \mathrm{~g}$ (wet $w \mathrm{t}$ ) $\mathrm{m}^{-2}$.

In contrast to the increase of oxidized nitrogen compounds, porewater ammonia concentrations decreased in the presence of Arenicola marina. Mean ammonia concentrations of 36 to $39 \mu \mathrm{mol} \mathrm{l}^{-1}$ were found in the control container, while in the container with $16 \mathrm{~A}$. marina ammonia concentrations of 24 to 27 umol $1^{-1}$ were measured. The decrease in ammonia concen-

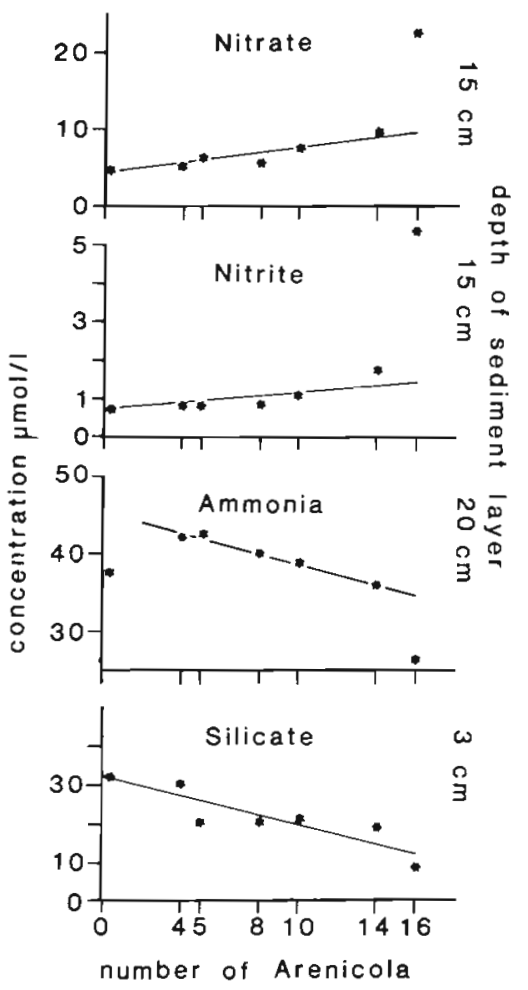

Fig. 4. Nutrient concentrations in the most affected sediment layers at the end of the container experiment

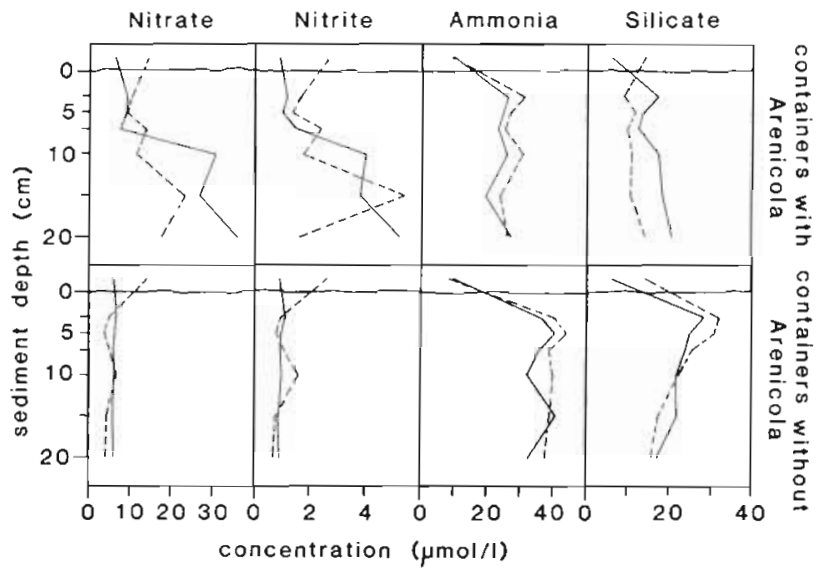

Fig. 5. Nutrient profiles in the container with 16 Arenicola marina and the container without $A$. marina measured in September (solid line) and October (broken line)

trations relative to $100 \mathrm{~g}$ (wet $\mathrm{wt}) \mathrm{m}^{-2}$ A. marina biomass was 0.42 to $0.85 \mu \mathrm{mol} \mathrm{l}^{-1}$ in the 15 to $20 \mathrm{~cm}$ depth layer.

Silicate concentrations also decreased with increasing Arenicola marina abundance as shown in Figs. 4 and 5. but in contrast to ammonia, the decrease in concentration was highest in the upper sediment layers between 3 and $7 \mathrm{~cm}$ depth. The decrease in silicate concentration in the sediment core calculated for the standard $A$. marina biomass of $100 \mathrm{~g}$ (wet wt) $\mathrm{m}^{-2}$ was 0.22 to $1.05 \mu \mathrm{mol} \mathrm{l} \mathrm{l}^{-1}$

\section{Sediment block experiment}

As determined by daily counts of fecal casts, the lugworms did not emigrate from the enclosed sediment blocks with increased Arenicola marina abundance. Feeding activities were normal and it was concluded that the polychaetes were not disturbed by enclosure and increased abundance.

The surface of the sediment block with integrated gauze mat for lugworm exclusion was easily distinguishable from the surrounding sediment. The surface was smooth, without any funnels or fecal casts and had a brownish colour presumably caused by a higher abundance of benthic diatoms.

The results of the container experiment were confirmed by the sediment block experiment. Highest nitrate concentrations were observed at $20 \mathrm{~cm}$ depth in the sediment block with increased Arenicola marina abundance. In contrast, the concentrations of nitrate measured in the sediment block without $A$. marina were significantly lower in the $20 \mathrm{~cm}$ depth layer compared with the sediment block inhabited by lugworms in natural abundance (Weir-test; Sachs 1978). The decreases in ammonia and silicate concentrations with increasing presence of A. marina measured in the container experiments also occurred in the sediment block 
Table 4. Nutrient concentrations in sediment containers without Arenicola marina and sediment containers with high $A$. marina abundance. Mean concentrations for the entire sediment core and for the layer where highest change in concentration was observed are listed. All concentrations are expressed in $\mu \mathrm{mol} \mathrm{l}^{-1}$

\begin{tabular}{|c|c|c|c|c|c|}
\hline \multicolumn{3}{|c|}{ September experıment } & \multicolumn{3}{|c|}{ October experiment } \\
\hline $\begin{array}{l}\text { Depth } \\
(\mathrm{cm})\end{array}$ & $\begin{array}{l}\text { Without } \\
\text { A. marina }\end{array}$ & $\begin{array}{l}\text { With } 16 \\
\text { A. marina }\end{array}$ & $\begin{array}{l}\text { Depth } \\
\text { (cm) }\end{array}$ & $\begin{array}{l}\text { Without } \\
\text { A. marina }\end{array}$ & $\begin{array}{l}\text { With } 16 \\
\text { A. marina }\end{array}$ \\
\hline \multicolumn{6}{|c|}{ Nitrate } \\
\hline $0-20$ & 6.2 & 23.2 & $0-20$ & 5.0 & 14.0 \\
\hline 20 & 6.4 & 35.9 & 15 & 4.6 & 23.2 \\
\hline \multicolumn{6}{|c|}{ Nitrite } \\
\hline $0-20$ & 1.0 & 3.3 & $0-20$ & 1.0 & 2.6 \\
\hline 15 & 0.9 & 3.8 & 15 & 0.8 & 5.5 \\
\hline \multicolumn{6}{|c|}{ Ammonia } \\
\hline $0-20$ & 36.3 & 24.9 & $0-20$ & 39.4 & 27.4 \\
\hline 15 & 40.8 & 20.1 & 20 & 37.6 & 26.4 \\
\hline \multicolumn{6}{|c|}{ Silicate } \\
\hline $0-20$ & 22.4 & 17.4 & $0-20$ & 22.2 & 11.2 \\
\hline 7 & 24.0 & 12.4 & 3 & 32.3 & 8.9 \\
\hline
\end{tabular}

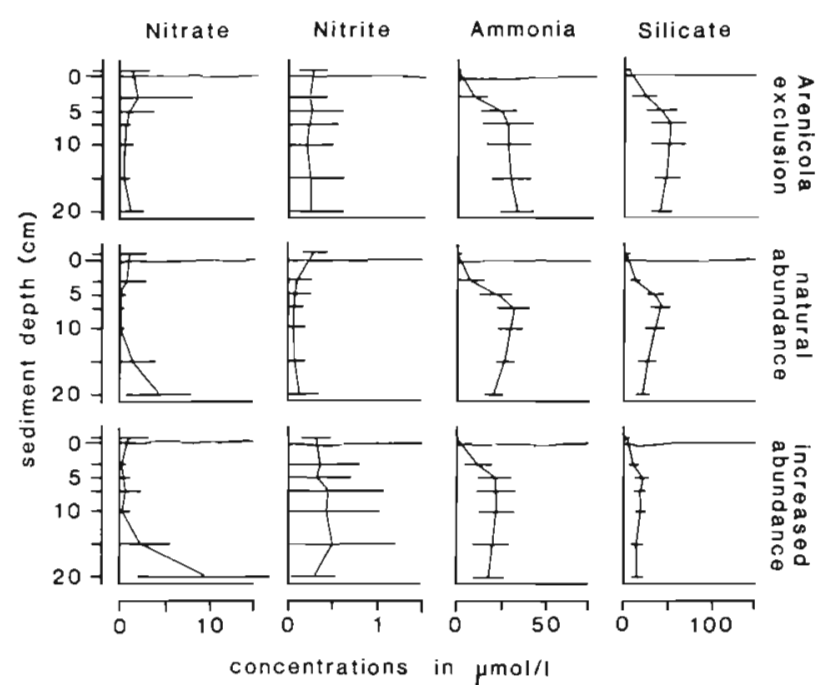

Fig. 6. Nutrient profiles in the sediment block without Arenicola marina (upper row), in the sediment block with natural abundance (middle row) and the sediment block with increased $A$. marina abundance (lower row). The figure includes all measurements made during the experiment; error bars indicate standard deviation

experiment at 10 to $20 \mathrm{~cm}$ depth. Results of the sediment block experiment are summarized in Fig. 6 and Table 5.

\section{DISCUSSION}

The presence of Arenicola marina causes an increase of nitrate in porewater at the depth of the burrow gallery, which is situated, depending on lugworm size, at 5 to $35 \mathrm{~cm}$ sediment depth. Bioturbation activities of the lugworms lower ammonia and silicate concentrations of the inhabited sediment layers. Different pro- cesses around the tail shaft, gallery, feeding pocket and head shaft of the burrow are involved in these changes of porewater composition.

\section{Processes in the tail shaft zone}

Peristaltic movements of Arenicola marina cause a waterflow of 40 to $400 \mathrm{ml} \mathrm{h}^{-1}$ through its L-shaped tube, supplying the polychaete with oxygen (Krüger 1964, Jacobsen 1967, Foster-Smith 1978, Baumfalk 1979). The burrow wall of the tail shaft, consisting of sand grains and detritus tightly cemented with mucus, is about $1 \mathrm{~mm}$ thick and relatively impermeable to porewater. A 2 to $4 \mathrm{~mm}$ thick halo of brownish oxic sediment surrounding the tube provides evidence of oxygen diffusion from the ventilation current into the burrow wall (Reise \& Ax 1979, Reise 1985). Hylleberg (1975) found an increased content of organic matter and lowered redox potential in the sediment around the tail shaft of Abarenicola pacifica burrows, a related species with a similar mode of burrowing and feeding. As reported by Aller \& Yingst (1978), Aller (1983) and Aller \& Aller (1986) burrow linings of marine polychaetes are characterized by local enhancement of bacterial activities and decomposition processes. Oxygen diffusing into the burrow wall is used by the intense bacterial activities associated with the wall. Excretions of $A$. marina increase ammonia concentration, bacterial activities and oxygen consumption in the gallery and tail shaft (Henriksen et al. 1983). Water flow through the tail shaft and gallery of the burrow, both lined with mucus and thereby rich in organic content and relatively impermeable, will not lead to a decrease of ammonia or silicate or to a substantial increase of nitrate in the porewater. 
Table 5. Nutrient concentrations in the sediment block without Arenicola marina, with natural A. marina abundance, and with increased A. marina abundance. Mean concentrations for the 3 to $20 \mathrm{~cm}$ depth layer and for the layer where the highest changes in concentrations were observed are listed. All concentrations expressed in umol $1^{-1} \pm$ standard deviation

\begin{tabular}{|c|c|c|c|}
\hline $\begin{array}{l}\text { Depth } \\
(\mathrm{cm})\end{array}$ & $\begin{array}{c}\text { A. marina exclusion } \\
\left(0 \text { ind. } \mathrm{m}^{-2}\right)\end{array}$ & $\begin{array}{c}\text { Natural abundance } \\
\text { (33 ind } \mathrm{m}^{-2} \text { ) }\end{array}$ & $\begin{array}{c}\text { Increased abundance } \\
\left(220 \text { ind } \mathrm{m}^{-2}\right)\end{array}$ \\
\hline \multicolumn{4}{|l|}{ Nitrate } \\
\hline $3-20$ & $1.1 \pm 1.5$ & $1.9 \pm 1.6$ & $3.4 \pm 2.2$ \\
\hline 20 & $1.4 \pm 1.5$ & $4.8 \pm 3.8$ & $9.9 \pm 7.6$ \\
\hline \multicolumn{4}{|l|}{ Nitrite } \\
\hline $3-20$ & $0.27 \pm 0.28$ & $0.13 \pm 0.13$ & $0.42 \pm 0.41$ \\
\hline 15 & $0.28 \pm 0.37$ & $0.11 \pm 0.13$ & $0.52 \pm 0.71$ \\
\hline \multicolumn{4}{|l|}{ Ammonia } \\
\hline $3-20$ & $27.4 \pm 8.0$ & $24.9 \pm 5.0$ & $20.6 \pm 9.1$ \\
\hline 20 & $31.9 \pm 9.4$ & $23.0 \pm 5.9$ & $18.8 \pm 9.9$ \\
\hline \multicolumn{4}{|l|}{ Silicate } \\
\hline $3-20$ & $43.3 \pm 9.8$ & $27.8 \pm 8.2$ & $17.8 \pm 5.4$ \\
\hline 7 & $50.2 \pm 21.0$ & $41.8 \pm 13.0$ & $21.4 \pm 7.6$ \\
\hline
\end{tabular}

\section{Processes in the feeding pocket zone}

The tube of the Arenicola marina burrow terminates at the end of the gallery where the ventilation current percolates into the sediment. A. marina squeezes the water into the sand of the feeding pocket. As it is not capable of extracting all free oxygen from the ventilation current (Shumway 1979), oxygenated water percolates into the sediment of the feeding pocket. Hylleberg (1975) found positive redox potentials in the zone of the feeding pocket and head shaft of Abarenicola pacifica burrows, whereas redox values near the gallery and tail shaft were much lower and negative. Another indication for the presence of oxygen in the feeding pocket is the concentration of aerobic, oxygen-dependent meiofauna organisms in this zone as reported by Reise \& Ax (1979) and Reise (1984).

The influx of oxygenated water promotes nitrification in the sediment layer at the depth of the feeding pocket. In the container experiment an increase in abundance of juvenile Arenicola marina led to a rise in nitrate concentrations at 15 to $20 \mathrm{~cm}$ depth. In the sediment block with increased abundance of adults, this increase in concentration of nitrate was observed at $20 \mathrm{~cm}$ depth. In contrast to these findings, nitrate concentrations decreased in the 15 to $20 \mathrm{~cm}$ depth layer of the sediment block from which $A$. marina was excluded.

\section{Processes in the head shaft zone}

The deposit feeder Arenicola marina ingests substrate of the feeding pocket, which mainly consists of surface sediment from the feeding funnel sliding down the head shaft of its burrow (Wells 1945, Jacobsen
1967). The shape of the quicksand column sinking down the head shaft depends on sediment structure but in most cases, is only about $5 \mathrm{~mm}$ in diameter and sharply separated from the surrounding sediment (Reise \& Ax 1979, Rijken 1979, Reise 1987). Most of the surface material transported into the sediment is swallowed by the polychaete and defecated on the sediment surface (Rijken 1979). It is concluded that the vertical particle transport caused is of minor importance in influencing porewater composition when compared with the effect of the ventilation current. As the loose material of the sinking sand column poses the least resistance to the ventilation current, the water pressed into the feeding pocket flows upward in the head shaft and emerges from the burrow from the feeding funnel (Wells 1945: Newell 1979, Rijken 1979). As the upflowing water is not separated from surrounding porewater by a mucuous burrow wall, extensive mixing and exchange processes between porewater and ventilation water take place while the water ascends from ca $20 \mathrm{~cm}$ depth to the sediment surface. This waterflow, directed from the living depth of $A$. marina up to the sediment surface, is responsible for the ammonia and silicate decreases observed in the containers and sediment block with $A$. marina.

\section{INVERSION OF NUTRIENT PROFILES}

In sediment containers, sediment block and sand flat densely inhabited by Arenicola marina, maximum concentrations of ammonia and silicate were measured in the 3.5 to $5 \mathrm{~cm}$ depth layer, in the zone of the redox potential discontinuity (RPD). Concentrations of these substances decreased below the RPD-layer. In 
contrast to these findings a decrease in nutrient concentrations below the RPD did not occur in the containers and the sediment block without A. marina. These results provide evidence that $A$. marina causes a decrease in ammonia and silicate concentrations in porewater below $5 \mathrm{~cm}$ sediment depth by pumping respiration water with low nutrient concentrations into deeper sediment layers. Inverted nutrient profiles characterized by increasing nitrate concentrations and decreasing ammonia and silicate concentrations with increasing sediment depth have also been reported from subtidal sediments. Emerson et al. (1984) found a minimum in ammonia and silicate concentrations at 20 to $30 \mathrm{~cm}$ depth in sediments of Puget Sound (Washington, USA) caused by the activities of cirratulid polychaetes and burrowing crustaceans. Bioturbation by the sea cucumber Molpadia intermedia results in a maximum of nitrate and nitrite and a minimum of silicate at 20 to $30 \mathrm{~cm}$ depth in Puget Sound sediments (Grundmanis \& Murray 1977). As a consequence of activities of the polychaetes Spiochaetopterus oculans and Maldanopsis elongata a decrease in silicate concentration is found in Narragansett Bay (Rhode Island, USA) sediments at 4 to $7 \mathrm{~cm}$ depth (McCaffrey et al. 1980). Bioturbation by the polychaete Clymenella torquata can generate an oxidized sediment layer at 10 to $30 \mathrm{~cm}$ depth (Rhoads 1973, 1974, Aller 1978).

The vertical profiles of interstitial ammonia, nitrate and nitrite concentrations indicate that nitrification occurs at 15 to $20 \mathrm{~cm}$ depth of the sandflat sediment with oxygen supplied by the ventilation current of Arenicola marina. The results of these container and sediment block experiments support the findings of Grundmanis \& Murray (1977) and Aller (1978, 1982) who observed an intermediate sediment layer in the anoxic sediment zone caused by endobenthic invertebrates pumping oxygenated water into their burrows. By enlarging the zone of nitrification A. marina promotes denitrification and thereby nitrogen release from the sediment. The transport of oxygenated water with the ventilation current into the sediment advances mineralization in the anoxic zone. Finally the irrigation water flowing through the burrow leaches nutrients out of the surrounding sediment and flushes them out of the bottom. It is concluded that A. marina plays an important role in the nutrient cycles of sand flats including the Wadden Sea.

Acknowledgements. My thanks are due to Prof. K. Reise for his advice and helpful discussions throughout this work. To Prof. W Noodt I am grateful for supervising this project. Gratitude is also expressed to Prof. S. Gerlach for his constructive criticism. I extend thanks to the staff of the Biologische Anstalt Helgoland/Litoralstation List who provided the facilities to carry out laboratory and field work.

\section{LITERATURE CITED}

Aller, J. Y., Aller, R. C. (1986). Evidence for localized enhancement of biological activity associated with tube and burrow structures in deep sea sediments at the Hebble Site, western North Atlantic. Deep Sea Res. 33 (6): 755-790

Aller, R. C. (1978). Experimental studies of changes produced by deposit feeders on pore water, sediment, and overlaying water chemistry. Am. J. Sci. 278: 1185-1234

Aller, R. C. (1982). The effects of macrobenthos on chemical properities of marine sediment and overlying water. In: McCall, P. L. Tevesz, M. J. S. (eds.) Animal-sediment relations. Plenum Press, New York

Aller, R. C. (1983). The importance of the diffusive permeability of animal burrow linings in determining marine sediment chemistry. J. mar. Res. 41: 299-322

Aller, R. C., Yingst, J. Y (1978). Biogeochemistry of tubedwellings: a study of the sedentary polychaete Amphitrite ornata (Leidy). J. mar Res. 36: 201-254

Aller, R. C., Yingst, J. Y (1985). Effects of the marine depositfeeders Heteromastus filiformis (Polychaeta), Macoma balthica (Bivalvia), and Tellina texana (Bivalvia) on averaged sedimentary solute transport, reaction rates, and microbial distributions. J. mar Res. 43: 615-645

Ashworth, J. H. (1904). Arenicola (The lug-worm). L.M.B.C Mem. typ. Br. mar Pl. Anim. 11 1-118

Asmus, R. (1986). Nutrient flux in short-term enclosures of intertidal sand communities. Ophelia 26: 1-19

Baumfalk, Y. A. (1979). On the pumping activity of Arenicola marina. Neth. J. Sea Res. 13: 422-427

Berner, R. A. (1971). Principles of chemical sedimentology. McGraw-Hill, New York

Berner, R. A. (1976). The benthic boundary layer from the viewpoint of a geochemist. In: McCave, I. N. (ed.) The benthic boundary layer. Plenum Press, New York, p. 35-55

Berner, R. A. (1979). Kinetics of nutrient regeneration in anoxic marine sediments. Physics Chem. Earth 11. 279-292

Berner, R. A. (1980). Early diagenesis - A theoretical approach. Princeton University Press, Princeton, New Jersey

Beukema, J. J., Cadée, G. C. (1986). Zoobenthos responses to eutrophication of the Dutch Wadden Sea. Ophelia 26: $55-65$

Emerson, S., Jahnke, R., Heggie, D. (1984). Sediment-water exchange in shallow water estuarine sediments. J. mar. Res 42: 709-730

Fauchald, K. F., Jumars, P. A. (1979). The diet of worms: a study of polychaete feeding guilds. Oceanogr. mar. Biol. A. Rev. 17. 193-284

Foster-Smith, R. L. (1978). An analysis of water flow in tube living animals. J. exp. mar Biol. Ecol. 34: 73-95

Gerlach, S. A. (1987). Pflanzennährstoffe und die Nordsee ein Überblick. Seevögel (Zeitschrift Verein Jordsand, Hamburg) 8 (4): 49-62

Grasshoff, K., Ehrhardt, M., Kremling, K. (1983). Methods of seawater analysis. Verlag Chemie, Weinheim

Grundmanis, V., Murray, J. W. (1977). Nitrification and denitrification in marine sediments from Puget Sound. Limnol. Oceanogr 22: 804-813

Guinasso, N. L., Schink, D. R. (1975). Quantitative estimates of biological mixing rates in abyssal sediments. J. geophys. Res. 80: 3032-3043

Henriksen, K., Rasmussen, M. B., Jensen, A. (1983). Effect of bioturbation on microbial nitrogen transformations in the sediment and fluxes of ammonium and nitrate to the overlaying water. Ecol. Bull. 35: 193-205 
Hylleberg. J. (1975). Selective feeding by Abarenicola pacifica with notes on Abarenicola vagabunda and a concept of gardening in lugworms. Ophelia 14: 113-137

Jacobsen, V (1967). Feeding in the lugworm Arenicola marina (L.): quantitative studies. Ophelia 4: 91-109

Krüger, F. (1959). Zur Ernährungsphysiologie von Arenicola marina. Zool. Anz. Suppl. 22: 115-120

Krüger. F. (1964). Versuche über die Abhängigkeit der Atmung von Arenicola marina (Annelides, Polychaeta) von Größe und Temperatur. Helgoländer wiss. Meeresunters. 10: $38-63$

Krüger. F. (1966). Messungen der Pumptätigkeit von Arenicola marina L. im Watt. Helgoländer wiss. Meeresunters. 11: 70-91

Krüger. F. (1971). Bau und Leben des Wattwurmes Arenicola marina. Helgoländer wiss. Meeresunters. 22: 149-200

McCaffrey, R. J., Myers, A. C., Davey, E., Morrison, G., Bender, M., Luedke, N., Cullen, D., Froelich, P., Klinkhammer, G. (1980). The relation between pore water chemistry and benthic fluxes of nutrients and manganese in Narrangansett Bay, Rhode Island. Limnol. Oceanogr. 25: 31-44

Newell, R. C. (1979). Biology of intertidal animals. Elsevier, New York

Reise, K. (1983). Experimental removal of lugworms from marine sands affects small zoobenthos. Mar. Biol. 74: $327-332$

Reise, K. (1984). Free-living Platyheleminthes (Turbellaria) of a marine sand flat: an ecological study. Microfauna Mar 1: $1-62$

Reise, K. (1985). Tidal flat ecology. Ecological Studies 54, Springer Verlag, Berlin

Reise, K. (1987). Experimental analysis of processes between

This article was submitted to the editor species on marine tidal flats in: Schulze, E. D., Zwölfer, H. (eds.) Ecological studies 61. Potentials and limitations of ecosystem analysis. Springer Verlag, Berlin, p. 391-400

Reise, K., Ax, P. (1979). A meiofaunal thiobios limited to the anaerobic sulfide system of marine sand does not exist. Mar. Biol. 54: 225-237

Rhoads, D. C. (1973). The influence of deposit - feeding benthos on water turbidity and nutrient recycling. A.m. J. Sci. 273: 1-22

Rhoads, D. C. (1974). Organism-sediment relations on the muddy sea floor. Oceanogr. mar. Biol. A. Rev. 12: 263-300

Rhoads, D. C., Aller, R. C., Goldhaber, M. B. (1977). The influence of colonizing benthos on physical properties and chemical diagenesis of the estuarine seafloor. In: Coull, B. C. (ed.) Ecology of marine benthos. University of South Carolina Press, Columbia, p. 113-138

Rijken, M. (1979). Food and food uptake in Arenicola marina. Neth. J. Sea Res. 13: 406-421

Sachs, L. (1978). Angewandte Statistik. Springer Verlag, Berlin

Shumway, S. E. (1979). The effects of body size, oxygen tension and mode of life on the oxygen uptake rates of polychaetes. Comp. Biochem. Physiol. 64 a: 273-278

Thiel, H., Grossmann, M., Spychala, H. (1984). Quantitative Erhebungen über die Makrofauna in einem Testfeld im Büsumer Watt und Abschätzung ihrer Auswirkungen auf den Sedimentverband. Die Küste 40: 259-318

Van Straaten, L. M. J. U. (1952). Biogene textures and the formation of shell beds in the Dutch Wadden Sea. I-II Proc. K. Ned. Akad. Wet. Ser. B, 55: 500-516

Wells, S. P. (1945). The mode of life in Arenicola marina L. J mar. biol. Ass. U. K. 26: 170-207

Manuscript first received: August 29, 1989

Revised version accepted: January 16, 1990 